\title{
Validitas dan Praktikalitas Modul Kesetimbangan Ion dan pH Larutan Garam Berbasis Inkuiri Terbimbing
}

\section{Validity and Practicality of Module of Ion Equilibrium and $\mathrm{pH}$ of Salt Solution on Guided Inquiry}

\author{
$S$ Rahayu ${ }^{1}$ and Iryani ${ }^{*}$ \\ ${ }^{1}$ Pendidikan Kimia, Universitas Negeri Padang, Jl. Prof. Dr. Hamka, Air Tawar Barat, \\ Padang Utara, Sumatera Barat, Indonesia 25171 \\ *iryaniachmad62@gmail.com
}

ARTICLE INFO

Received 03 January 2020

Revised 22 January 2020

Published 06 February 2020

\begin{abstract}
This study aims to produce a module ion equilibrium and $p H$ of salt solution and how to categorise module validity and practicality levels. As this is Research and Development study, we used Plomp model consisting three stages, preliminary research, prototyping stage and assessment phase. Guided inquiry is a learning model used in this study. This module is validated by 5 validators with a research instrument in validation and practicality sheet in the form of questionnaires. The validator's evaluation of each statement was analysed using Kappa Cohen formula. The results show kappa moment value ( $\kappa$ ) 0.85 with a very high category. The kappa moment value $(\kappa)$ for practicality of module based on teacher's response is 0.88 , while student's response is 0.81 . The resulting module is very valid and practical to use.
\end{abstract}

\section{KEYWORDS}

Module, Ion Equilibrium and $p H$ Salt Solution, Guided Inquiry, Validity, Practicality

\section{ABSTRAK}

Penelitian ini bertujuan untuk menghasilkan modul kesetimbangan ion dan pH larutan garam, serta menentukan kategori validitas dan praktikalitasnya. Jenis penelitian ini menggunakan Research and Development, sedangkan model pengembangan yang dipakai adalah model Plomp meliputi tiga tahapan yaitu preliminary research, prototyping stage dan assessment phase. Inkuiri terbimbing merupakan model pembelajaran yang digunakan pada penelitian ini. Modul ini divalidasi oleh 5 orang validator dengan instrumen penelitian berupa lembar validasi dan praktikalitas berupa angket. Penilaian validator terhadap masing-masing pernyataan dianalisis dengan menggunakan formula Kappa Cohen. Hasil validasi menunjukkan nilai rerata momen kappa (к) sebesar 0,85 berkategori sangat tinggi. Nilai rerata momen kappa (к) untuk praktikalitas modul dari respon guru sebesar 0,88 , sedangkan dari respon siswa sebesar 0,81 . Modul yang dihasilkan sangat valid dan praktis untuk digunakan.

\section{KATA KUNCI}

Modul, Kesetimbangan Ion dan $\mathrm{pH}$ Larutan Garam, Inkuiri Terbimbing, Validitas, Praktikalitas 


\section{PENDAHULUAN}

Kimia adalah salah satu mata pelajaran bidang Ilmu Pengetahuan Alam dan sebagian besar dipelajari pertama kali di Sekolah Menengah Atas (SMA). Banyak orang yang beranggapan bahwa mata pelajaran kimia merupakan salah satu mata pelajaran yang sangat sulit dan membosankan. Dalam pembelajarannya siswa dituntut terlibat aktif sehingga kimia tidak terasa membosankan, dengan kata lain pembelajaran tersebut berpusat pada peserta didik. Hal ini juga merupakan tuntutan dari kurikulum 2013. Tujuan yang ingin dicapai melalui penggunaan kurikulum 2013 adalah untuk mempersiapkan manusia Indonesia agar memiliki kemampuan hidup sebagai pribadi dan warga negara yang beriman, produktif, kreatif, inovatif, dan afektif serta mampu berkontribusi pada kehidupan bermasyarakat, berbangsa, bernegara dan peradaban dunia ${ }^{[1]}$.

Peserta didik dituntut untuk mempunyai kemampuan berpikir tingkat tinggi atau HOTS (High Order Thinking Skill). Kemampuan berpikir tingkat tinggi mencakup kemampuan berpikir kritis, logis, reflektif, metakognitif dan kreatif ${ }^{23}$. Model pembelajaran yang dapat dipakai diantaranya: pembelajaran berbasis penemuan (discovery learning), pembelajaran berbasis penelitian (inquiry learning) dan pembelajaran berbasis pemecahan masalah untuk menghasilkan suatu karya (project based learning).Penggunaan modul berbasis inkuiri terbimbing merupakan salah satu upaya yang dilakukan agar pembelajaran kimia tidak membosankan. Upaya ini juga dapat membantu siswa menemukan konsep-konsep materi yang bersifat abstrak, serta siswa lebih paham, lebih ingat dan aktif selama proses pembelajaran.

Penerapan inkuiri terbimbing dalam proses pembelajaran terdiri dari 5 tahapan meliputi orientasi, eksplorasi, penemuan konsep atau pembentukan konsep, aplikasi, dan penutup ${ }^{[3]}$. Proses belajar dengan menggunakan bahan ajar modul berbasis inkuiri terbimbing akan memungkinkan siswa untuk memiliki kecepatan belajar yang tinggi dalam menyelesaikan satu $\mathrm{KD}$ atau lebih dibandingkan siswa yang tidak menggunakan modul.

Modul berbasis inkuiri terbimbing memiliki beberapa kelebihan. Pertama, adanya model dan pertanyaan kunci yang terdapat pada modul, akan mendorong siswa untuk berfikir kritis dan analitis dalam menemukan konsep. Siswa akan menganalisis model dan menjawab pertanyaan kunci yang disajikan, kemudian mengkonstruk pengetahuannya sehingga diperoleh suatu konsep sesuai dengan tujuan pembelajaran. Kedua, modul berisi latihan dan soal yang merupakan aplikasi langsung dari konsep yang diperoleh. Untuk meningkatkan pemahaman siswa terhadap materi, latihan dan soal dapat membantu siswa dalam hal ini. Ketiga, penyajian modul dibuat semenarik mungkin dilengkapi dengan warna, sehingga dapat meningkatkan minat siswa untuk belajar. Terkait bahan ajar dalam proses pembelajaran, Dinas Pendidikan Sumatera Barat mengimbau agar proses pembelajaran dikaitkan dengan nilainilai Al-Qur'an dan Budaya Alam Minangkabau hal ini sejalan dengan KI 1 dan KI 2 yaitu kompetensi religius dan sosial ${ }^{[4]}$.

Materi pembelajaran kimia kelas XI salah satunya adalah materi kesetimbangan ion dan $\mathrm{pH}$ larutan garam yang dipelajari pada semester genap. Materi ini merupakan materi yang banyak mengandung fakta, konsep dan prosedur. Berdasarkan hasil wawancara bersama guru kimia di SMAN 5 Padang dan SMAN 12 Padang serta hasil angket diketahui bahwa dalam proses pembelajaran kimia, guru dan siswa umumnya hanya menggunakan buku paket dan LKPD (Lembar Kegiatan Peserta Didik). Hasil wawancara dengan guru kimia diketahui bahwa di sekolah tersebut tidak ada yang menggunakan modul sebagai penunjang dalam proses pembelajaran. Menurut guru, belajar dengan buku paket dan LKPD belum efektif dalam membantu siswa untuk menemukan dan memahami konsep-konsep materi. Bahan ajar yang dipakai belum pula terintegrasi dengan nilainilai Al-Qur'an dan Budaya Alam Minangkabau.

Penggunaan modul berbasis inkuiri terbimbing telah terbukti kevalidan dan kepraktisannya dapat memberikan pengaruh positif terhadap hasil belajar siswa ${ }^{[5]}$. Penelitian tentang modul kimia berbasis inkuiri terbimbing dinyatakan bisa untuk digunakan dalam proses pembelajaran kimia,serta dapat meningkatkan hasil belajar siswa ${ }^{[6]}$. Selanjutnya, penelitian pengembangan modul berbasis inkuiri terbimbing pada materi hidrolisis garam yang valid dan praktis dengan penyajian secara multipel representasi mencakup level makroskopik, submikroskopik dan simbolik ${ }^{[7]}$.

Berdasarkan uraian di atas, penulis telah melakukan penelitian untuk menguji validitas dan praktikalitas modul yang telah dikembangkan dalam bentuk modul kesetimbangan ion dan $\mathrm{pH}$ larutan garam berbasis inkuiri terbimbing dengan judul "Validitas dan Praktikalitas Modul Kesetimbangan Ion dan $\mathrm{pH}$ Larutan Garam Berbasis Inkuiri Terbimbing”.

\section{METODE}

Penelitian ini termasuk dalam metode penelitian dan pengembangan atau Research and Development (R\&D). Model pengembangan yang digunakan adalah model Plomp yang dikembangkan oleh Tjeered Plomp, model Plomp ini meliputi 3 tahapan yaitu tahap penelitian awal (preliminary research), tahap pembuatan prototipe (prototyping stage) dan tahap penilaian (assessment phase) ${ }^{[8]}$. Penelitian ini dilakukan sampai tahap pengujian validitas dan praktikalitas terhadap modul yang dikembangkan. Subjek penelitian ini yaitu 2 orang dosen kimia FMIPA UNP, 3 orang guru dan siswa kelas XII SMAN 5 Padang. 
Tahap penelitian awal (preliminary research), kegiatan yang dilakukan pada tahap ini yaitu: (a) analisis kebutuhan dilakukan dengan cara mewawancarai guru kimia SMA dan menyebarkan angket kepada siswa; (b) mengidentifikasi materimateri pokok merupakan langkah pada tahap analisis konteks, indikator dan tujuan pembelajaran adalah hasil akhir pada tahap ini; (c) studi literatur bertujuan untuk mencari sumber-sumber yang berkaitan dengan pengembangan penelitian yang akan dilakukan serta memahami-nya; (d) pengembangan kerangka konseptual dilakukan dengan cara menganalisis konsep-konsep penting yang harus ada pada modul yang dikembangkan.

Tahap pembentukan prototipe (prototyping stage), tahap ini terbagi menjadi 3 bagian yaitu (a) pembentukan prototipe I, berisi perancangan dan penetapan unsur-unsur yang harus ada pada modul; (b) pembentukan prototipe II, prototipe II dihasilkan dari hasil revisi terhadap prototipe I yang telah dilakukan evaluasi formatif berupa evaluasi diri sendiri. Evaluasi ini menggunakan sistem check list terhadap unsur-unsur yang harus ada pada modul; (c) pembentukan prototipe III, uji coba satu-satu (one to one evaluation) dan penilaian para ahli (expert review) diperlukan pada tahap ini.3 orang siswa dijadikan sebagai responden pada tahap uji coba satu-satu. (d) pembentukan prototipe IV, dilakukan uji coba kelompok kecil (small group evaluation). Tahap penilaian (assesment phase), tahap ini dilakukan uji lapangan (field test) untuk mendapatkan tingkat praktikalitas dari modul yang dihasilkan.

Validitas berhubungan dengan ketepatan, suatu alat ukur dikatakan valid jika dapat mengukur apa yang hendak diukur secara tepat ${ }^{[9]}$. Praktikalitas berhubungan dengan tingkat kemudahan penggunaan dan pelaksanaan modul yang dihasilkan. Instrumen validasi dan praktikalitas pada penelitian ini adalah lembar validasi dan lembar praktikalitas.

Validasi dan praktikalitas dilakukan untuk menentukan kategori kevalidan dan kepraktisan modul yang dibuat. Validasi dilakukan oleh dua dosen kimia FMIPA UNP dan tiga orang guru SMA melalui lembar validasi, sedangkan praktikalitas diperoleh melalui respon angket oleh guru dan siswa SMA. Tahap analisis validitas dan praktikalitas menggunakan teknik categorical judgments yang dikembangkan oleh Boslaugh. Data validasi dan praktikalitas yang diperoleh akan dianalisis menggunakan formula kappa cohen di bawah ini.

$$
\text { momen } \operatorname{kappa}(\kappa)=\frac{\rho_{0}-\rho_{e}}{1-\rho_{e}}
$$

Keterangan:

$\kappa=$ nilai momen kappa

$\rho_{e}=$ proporsi yang terealisasi

$\rho_{0}=$ proporsi yang tidak terealisasi
Tabel 1. Kategori Kevalidan Berdasarkan Momen Kappa $^{[10]}$

\begin{tabular}{c|c} 
Interval & Kategori \\
\hline$<0,00$ & Tidak valid \\
\hline $0,00-0,20$ & Sangat rendah \\
\hline $0,21-0,40$ & Rendah \\
\hline $0,41-0,60$ & Sedang \\
\hline $0,61-0,80$ & Tinggi \\
\hline $0,81-1,00$ & Sangat tinggi
\end{tabular}

\section{HASIL DAN DISKUSI}

\subsection{Tahap Penelitian Awal (Preliminary \\ Research)}

Tahap penelitian awal terdiri dari beberapa tahapan yaitu tahapan analisis kebutuhan, analisis konteks, studi literatur dan kerangka konseptual.

\subsubsection{Analisis Kebutuhan}

Pada tahap ini telah dilakukan wawancara dengan 2 orang guru kimia SMA di kota Padang yaitu SMAN 5 Padang dan SMAN 12 Padang, serta penyebaran angket kepada 100 orang siswa kelas XII SMAN 5 Padang dan 100 orang siswa kelas XII SMAN 12 Padang. Setelah dilakukan analisis terhadap data yang diperoleh dari wawancara dan penyebaran angket diperoleh hasil sebagai berikut: (1) Banyak siswa yang menganggap materi kesetimbangan ion dan $\mathrm{pH}$ larutan garam sulit. (2) Bahan ajar yang digunakan di sekolah masih berupa LKS/LKPD dan buku paket yang belum dilengkapi dengan soal-soal HOTS. (3) Tahapan model pembelajaran inkuiri terbimbing belum termuat pada bahan ajar yang digunakan serta penyajiannya masih kurang menarik. (4) Bahan ajar juga belum terintegrasi dengan nilai-nilai Al-Qur'an dan Budaya Alam Minangkabau.

\subsubsection{Analisis Konteks}

Tahap analisis konteks dilakukan dua analisis yaitu analisis kurikulum dan analisis silabus. Berdasarkan analisis kurikulum diperoleh hasil bahwa kurikulum 2013 revisi 2018, menuntut proses pembelajaran berpusat pada siswa (student center) dan siswa harus memiliki kemampuan berpikir tingkat tinggi. Analisis yang dilakukan selanjutnya adalah analisis silabus meliputi analisis kompetensi dasar dan menguraikannya menjadi indikator pencapaian kompetensi serta tujuan pembelajaran. Kompetensi dasar yang dianalisis adalah kompetensi dasar 3.11 Menganalisis kesetimbangan ion dalam larutan garam dan menentukan pH-nya dan kompetensi dasar 4.11 Melaporkan tentang sifat asam basa berbagai larutan garam. Berdasarkan kompetensi dasar tersebut dirumuskan indikator pencapaian kompetensi yaitu : 1) Menganalisis 
sifat garam yang terhidrolisis dalam air berdasarkan kekuatan asam dan basa penyusunnya berdasarkan model yang disajikan. 2) Menganalisis garamgaram yang tidak mengalami hidrolisis, mengalami hidrolisis parsial dan yang mengalami hidrolisis total berdasarkan model yang disajikan. 3) Menghitung nilai $\mathrm{pH}$ larutan garam yang mengalami hidrolisis. 4) Melakukan eksperimen untuk menentukan $\mathrm{pH}$ larutan garam dengan menggunakan indikator universal. 5) Menganalisis $\mathrm{pH}$ larutan garam dari hasil percobaan dengan tepat. 6) Menganalisis sifat asam-basa dari suatu larutan garam dengan benar. Berdasarkan indikator pencapaian kompetensi di atas dapat dirumuskan tujuan pembelajaran yang harus dicapai siswa dalam mempelajari materi ini.

\subsubsection{Studi Literatur}

Tahap studi literatur bertujuan untuk mencari dan memahami jurnal terkait penelitian yang dilakukan, selain jurnal juga dipahami bukubuku dan beberapa sumber lainnya. Diantaranya (1) komponen-komponen modul dirujuk dari Suryosubroto $1983^{[11]}$. (2) Konten (isi materi) yang terdapat pada modul dirujuk dari buku-buku perguruan tinggi. (3) Model pembelajaran berbasis inkuiri terbimbing dan keterampilan berpikir tingkat tinggi dirujuk dari jurnal, buku dan sumber lainnya seperti internet.

\subsubsection{Kerangka Konseptual}

Tahap pengembangan kerangka konseptual dilakukan dengan cara menganalisis konsep. Hasil analisis konsep didapat beberapa poin yang harus dipahami oleh siswa antara lain: kesetimbangan larutan, tetapan hidrolisis garam, hidrolisis garam, hidrolisis sebagian, hidrolisis total, hidrolisis anion, hidrolisis kation, dll.

\subsection{Tahap Pembentukan Prototipe (Prototyping Stage)}

Tahap ini menghasilkan empat prototipe. Produk akhir akan dihasilkan melalui evaluasi formatif terhadap masing-masing prototipe awal. Rincian hasil dari tahapan pembentukan prototipe ini diuraikan sebagai berikut.

\subsubsection{Prototipe I}

Prototipe I merupakan hasil dari perancangan dan disesuaikan dengan penelitian awal. Prototipe I yang dihasilkan adalah berupa modul yang mempunyai komponen diantaranya cover, kata pengantar, daftar isi, daftar gambar, daftar tabel, peta konsep, petunjuk penggunaan modul, kompetensi inti, kompetensi dasar, indikator pencapaian kompetensi, tujuan pembelajaran, lembaran kegiatan, lembaran kerja, lembaran evaluasi, kunci lembaran kerja, kunci lembaran evaluasi dan kepustakaan. Modul yang dihasilkan terdiri dari dua aktivitas yaitu aktivitas kelas dan aktivitas laboratorium yang sesuai dengan tahapantahapan model pembelajaran inkuiri terbimbing yaitu terdiri atas tahap orientasi, tahap eksplorasi, tahap pembentukan konsep, tahap aplikasi dan tahap penutup. Rincian hasil dari masing-masing tahapan inkuiri terbimbing adalah sebagai berikut.

\subsubsection{Tahap Orientasi}

Pada tahap ini berisikan indikator yang harus dicapai siswa dan motivasi yang berfungsi untuk meningkatkan ketertarikan siswa terhadap materi yang akan dipelajari serta dapat menguasai materi prasyarat sebelum mempelajari materi ini. Contoh rancangan tahap orientasi yang telah dibuat pada modul adalah pada Gambar 1.

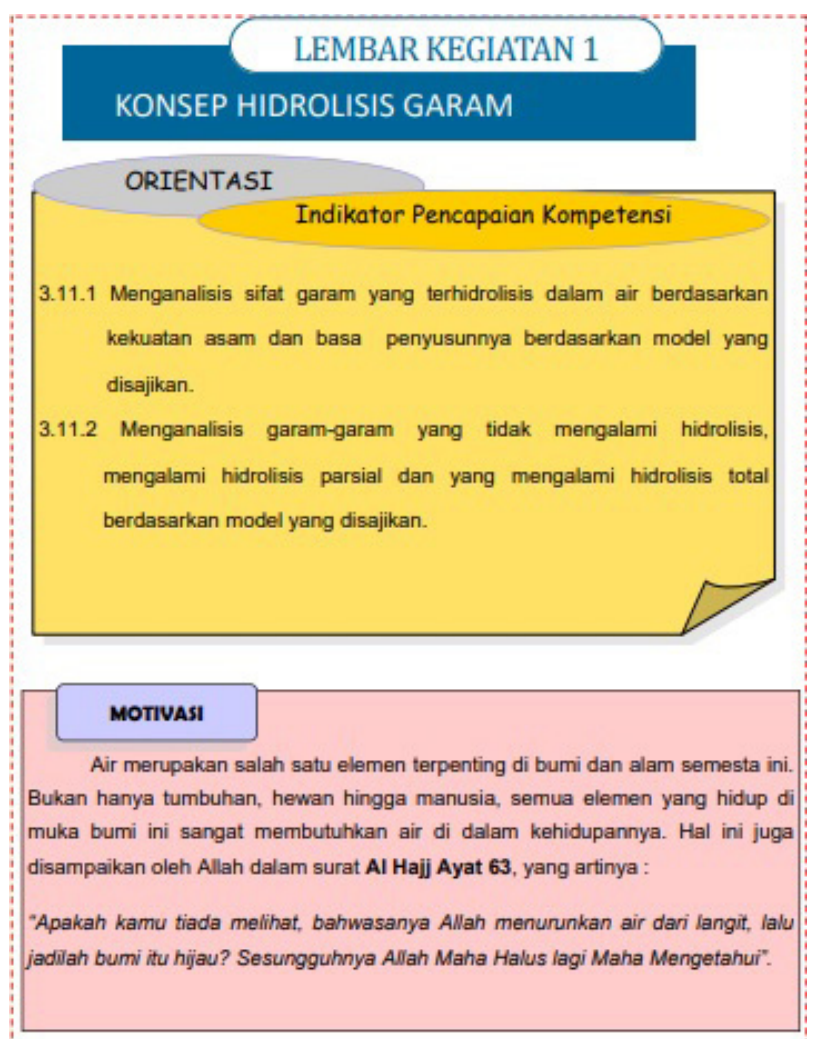

Gambar 1. Tahap orientasi

\subsubsection{Tahap Eksplorasi dan Pembentukan Konsep}

Pada tahap ini siswa mengeksplorasi model yang disajikan serta menjawab pertanyaan kunci yang digunakan sebagai penuntun bagi siswa untuk menemukan konsep. Pertanyaan kunci ini disusun dari ranah kognitif terendah sampai ke yang tertinggi. Rancangan tahap eksplorasi dan pembentukan konsep adalah pada Gambar 2.

\subsubsection{Tahap Aplikasi}

Konsep yang telah ditemukan siswa pada tahap sebelumnya akan dimantapkan lagi melalui soal-soal latihan yang diberikan kepada siswa. Soalsoal latihan yang dibuat berbentuk esai dan pilihan ganda, serta dibuat dari ranah kognitif $\mathrm{C} 4$ dengan maksud untuk melatih keterampilan berpikir tingkat tinggi siswa. Rancangan tahap aplikasi dapat dilihat pada Gambar 3.

\subsubsection{Tahap Penutup}

Pada tahap ini siswa dapat menyimpulkan materi yang telah dipelajari. Rancangan tahap penutup dapat dilihat pada Gambar 4. 


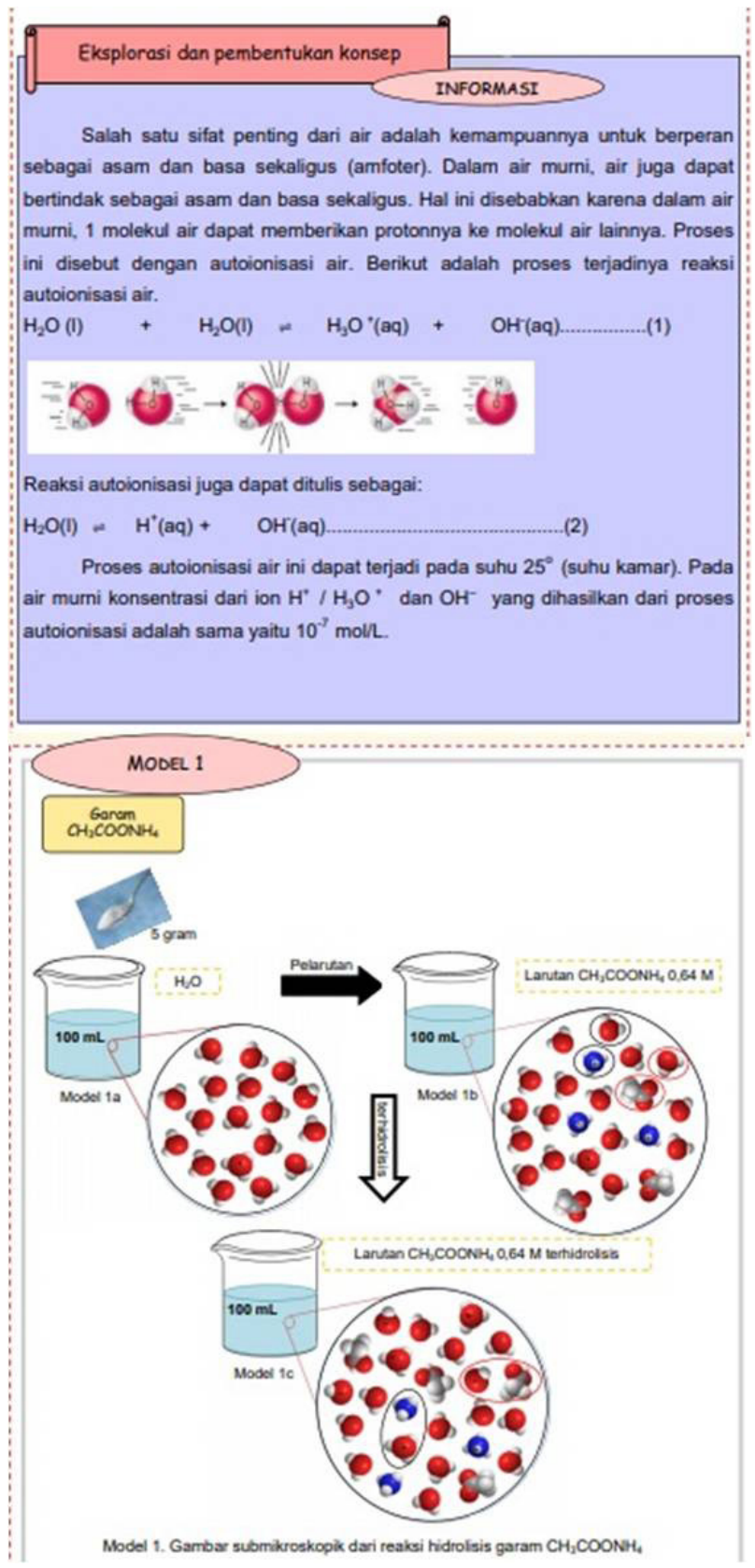

Gambar 2. Tahap eksplorasi dan pembentukan konsep

Prototipe I yang dihasilkan dilengkapi dengan soal-soal tipe HOTS yang bertujuan untuk meningkatkan keterampilan berpikir tingkat tinggi siswa. Prototipe ini juga diintegrasikan dengan nilai-nilai Al-Qur'an dan Budaya Alam Minangkabau sesuai dengan anjuran Dinas Pendidikan Provinsi Sumatera Barat pada tahun 2017.

\subsubsection{Prototipe II}

Evaluasi formatif berupa evaluasi diri sendiri terhadap prototipe I yang telah dihasilkan dilakukan pada tahap ini. Berdasarkan hasil evaluasi yang telah dilakukan disimpulkan bahwa prototipe I yang dihasilkan masih memerlukan revisi, ada beberapa komponen modul yang ditambahkan setelah melakukan evaluasi diri sendiri diantaranya daftar tabel, kunci jawaban lembaran kerja dan kunci jawaban lembaran evaluasi. Hasil dari perbaikan terhadap prototipe I ini disebut sebagai prototipe II.

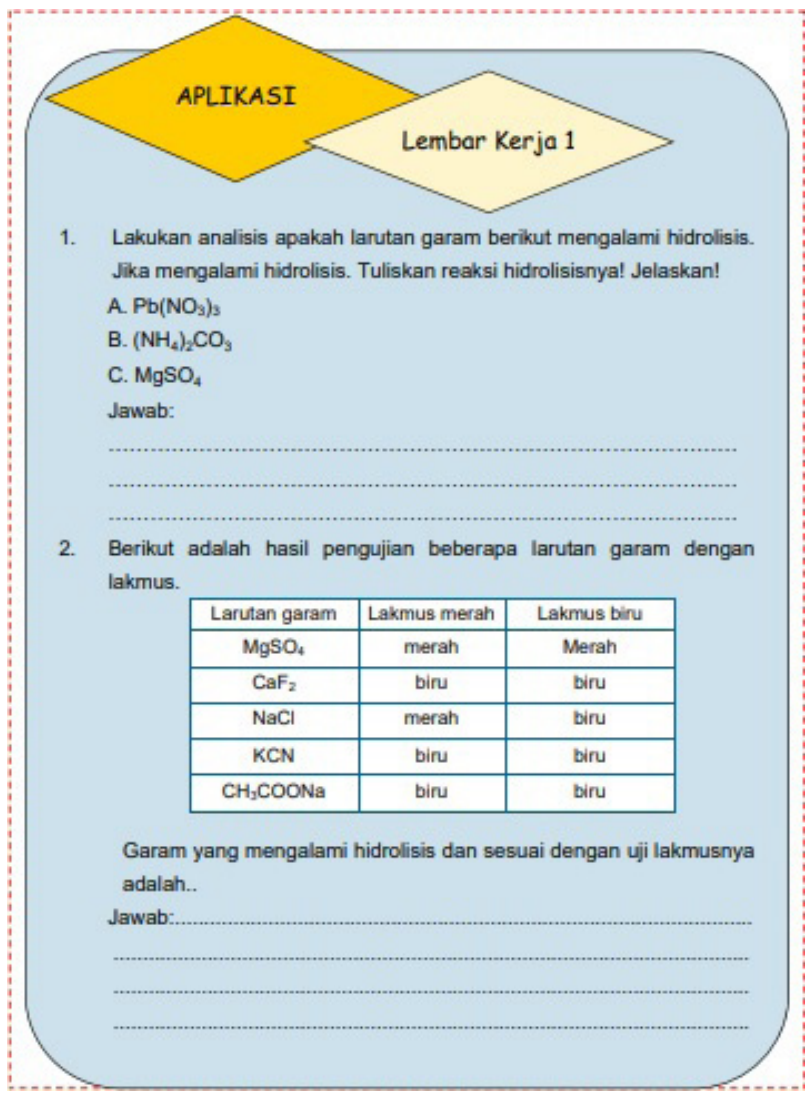

Gambar 3. Tahap aplikasi

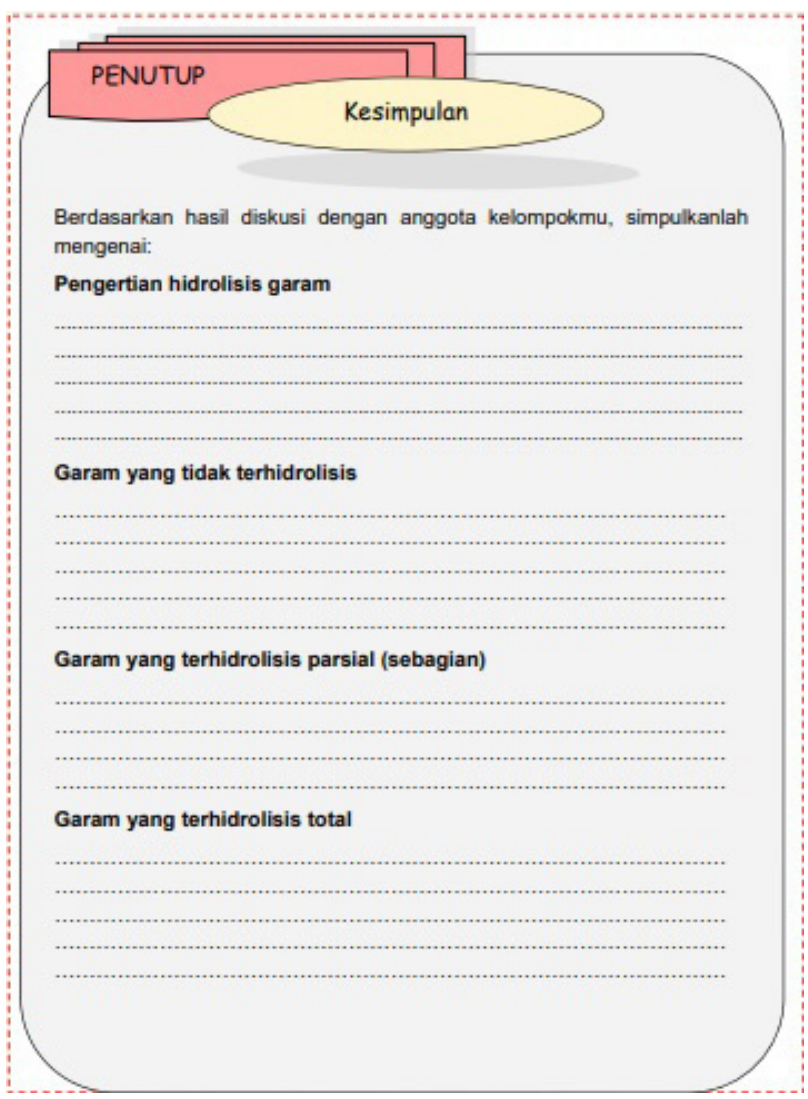

Gambar 4. Tahap penutup 


\subsubsection{Prototipe III}

Pada tahap ini dilakukan uji coba satusatu dan penilaian ahli. 3 orang siswa SMAN 5 Padang dijadikan sebagai responden pada uji coba satu-satu ini melalui kegiatan wawancara. Siswa yang diwawancarai ini dibedakan dari tingkatan ranah kognitifnya (siswa berkemampuan tinggi, berkemampuan menengah dan berkemampuan rendah). Berdasarkan wawancara yang telah dilakukan dengan siswa, respon positif diberikan oleh siswa terhadap modul yang dikembangkan. Rata-rata siswa menilai modul yang dikembangkan sudah menarik baik dari segi penyajian maupun dari segi konten.

Uji coba selanjutnya yaitu penilaian ahli dengan tujuan untuk mengetahui kategori kevalidan modul yang dikembangkan. Tingkat kevalidan modul dapat dinilai dari beberapa komponen meliputi: pertama, komponen kelayakan isi yang mencakup beberapa poin (a) kesesuaian dengan KD; (b) kesesuaian dengan kebutuhan bahan ajar; (c) kebenaran substansi materi pembelajaran; (d) manfaat untuk penambahan wawasan.

Kedua, komponen kebahasaan yang mencakup poin-poin berikut (a) Keterbacaan; (b) kejelasan informasi; (c) menggunakan kaidah bahasa Indonesia yang baik dan benar; (d) penggunaan bahasa secara efektif dan efisien (jelas dan singkat).

Ketiga, komponen Penyajian dengan indikator penilaian (a) kejelasan tujuan (indikator) yang ingin dicapai; (b) urutan penyajian modul; (c) pemberian motivasi dan daya tarik; (d) Interaksi (pemberian stimulus dan respon); (e) kelengkapan informasi.

Keempat, Komponen Kegrafikan meliputi unsur (a) penggunaan jenis dan ukuran huruf yang tepat; (b) layout atau tata letak; (c) ilustrasi, gambar dan foto; (d) desain tampilan.

Modul ini divalidasi oleh lima orang validator yaitu dua orang dosen kimia serta tiga orang guru SMAN 5 Padang. Hasil analisis data validasi modul terhadap beberapa aspek bisa dilihat pada Gambar 5.

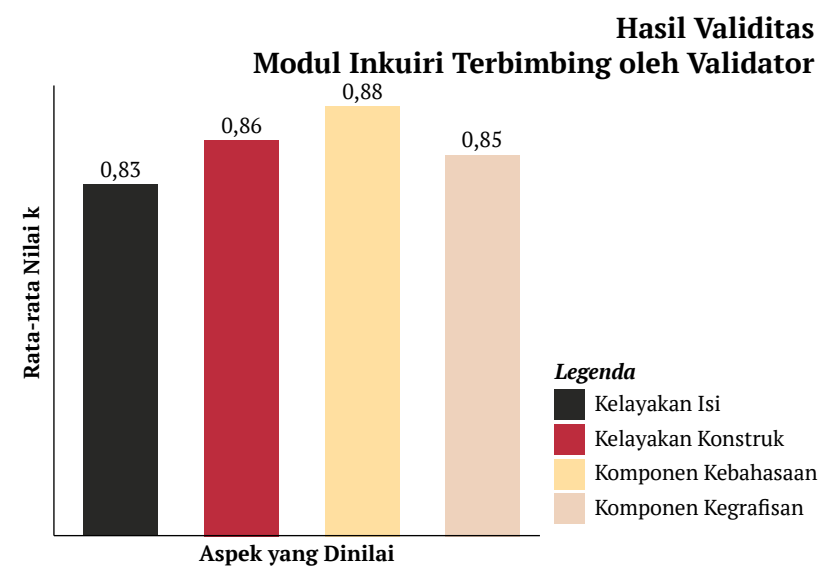

Gambar 5. Rata-rata momen kappa validitas modul oleh validator

Berdasarkan gambar di atas terlihat bahwa kelayakan isi dari modul adalah sebesar 0,83, kelayakan konstruk 0,86 , komponen kebahasaan 0,88 dan komponen kegrafisan 0,85. jika diartikan berdasarkan kategori momen kappa $(\kappa)$, maka semua aspek yang dinilai meliputi kelayakan isi, kelayakan konstruk, komponen kebahasaan dan komponen kegrafisan berkategori sangat tinggi.

Berdasarkan masing-masing aspek yang dinilai, bisa disimpulkan bahwa kategori kevalidan prototipe II yang dihasilkan adalah sangat tinggi dengan rata-rata nilai momen kappa $(\kappa) 0,85$. Saat melakukan validasi dengan ahli (2 orang dosen dan 3 orang guru kimia SMAN 5 Padang) ada beberapa saran yang diberi-kan oleh validator, maka akan dilakukan revisi lagi pada produk yang dikembangkan sehingga akan dihasilkan prototipe III.

\subsubsection{Prototipe IV}

Prototipe III yang telah dihasilkan pada tahap sebelumnya, dilakukan uji coba formatif berupa uji coba kelompok kecil (small group evaluation). Hasil dari uji coba ini didapatkan ratarata nilai momen kappa sebesar 0,86. Hasil ini termasuk dalam kategori kepraktisan sangat tinggi.

\subsection{Tahap Penilaian (Assessment Phase)}

Tahap penilaian (Assessment Phase) dilakukan uji lapangan (Field Test) terhadap prototipe IV yang telah dihasilkan. Data praktikalitas diperoleh melalui respon angket yang diberikan kepada guru dan siswa kelas XII. Hasil data praktikalitas dapat dilihat pada Gambar 6.

\section{Hasil Uji Praktikalitas}

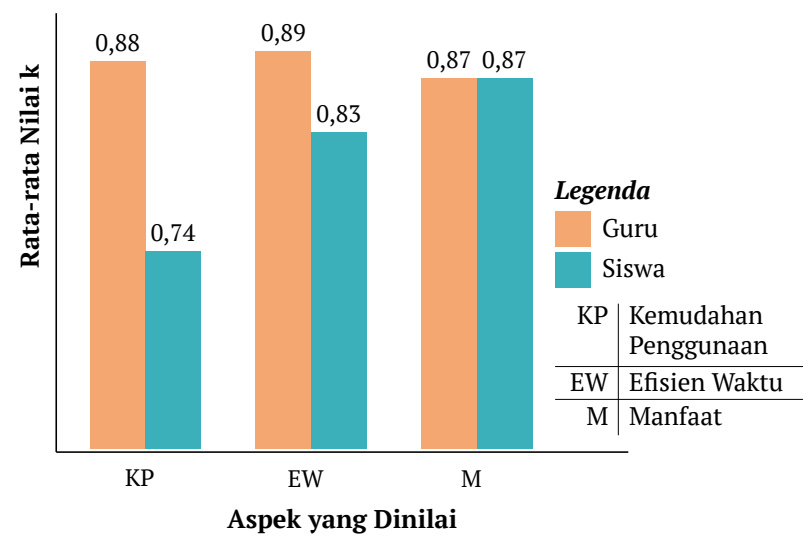

Gambar 6. Rata-rata momen kappa praktikalitas guru dan siswa

Berdasarkan gambar di atas terlihat bahwa nilai hasil uji praktikalitas melalui angket respon guru dari aspek kemudahan penggunaan sebesar 0,88 berkategori sangat tinggi, Efisiensi waktu 0,89 dengan kategori sangat tinggi dan aspek manfaat 0,87 tergolong kategori sangat tinggi dengan nilai rata-rata momen kappa 0,88. Hasil ini termasuk berkategori sangat tinggi.

Berdasarkan angket respon siswa, didapatkan nilai momen kappa dari aspek kemudahan penggunaan sebesar 0,74 dengan kategori tinggi, efisiensi waktu 0,83 berkategori sangat tinggi dan aspek manfaat 0,87 berkategori 
sangat tinggi dengan nilai rata-rata momen kappa 0,81 . Hasil ini tergolong kategori kepraktisan sangat tinggi.

Pada modul juga dilakukan analisis jawaban siswa. Berdasarkan analisis jawaban pertanyaan kunci dan kesimpulan diperoleh rata-rata nilai siswa 81. Hal membuktikan bahwa antara jawaban siswa pada modul dan penilaian siswa berdasarkan angket respon siswa memiliki hubungan yang relevan yaitu berkategori baik.

Selain analisis jawaban pertanyaan kunci dan kesimpulan, juga dilakukan analisis jawaban terhadap soal-soal HOTS yang ada pada modul. Persentase rata-rata siswa mampu menjawab soal tipe HOTS atau ranah kognitif C4 (aspek analisis) pada tahap aplikasi dan evaluasi adalah sebesar $71,5 \%$ dan $76,9 \%$.

\section{SIMPULAN}

Berdasarkan penelitian yang telah dilakukan, dapat disimpulkan bahwa modul kesetimbangan ion dan $\mathrm{pH}$ larutan garam berbasis inkuiri terbimbing yang dihasilkan dengan menggunakan model pengembangan Plomp memiliki tingkat kevalidan sangat tinggi dengan nilai momen kappa (к) 0,85 serta tingkat kepraktisan sangat tinggi dengan rata-rata nilai momen kappa(к) berdasarkan angket respon guru sebesar 0,88 dan angket respon siswa sebesar 0,81 .

\section{REFERENSI}

1. RI P. Perubahan Atas Peraturan Menteri Pendidikan Dan Kebudayaan Nomor 59 Tahun 2014 Tentang Kurikulum 2013 Sekolah Menengah Atas/Madrasah Aliyah. 2018.

2. Sani RA. Pembelajaran Berbasis HOTS (Higher Order Thinking Skills). Tanggerang: Tira Smart; 2019.

3. Hanson DM. Designing Process-Oriented Guided-Inquiry Activities. Pacific Crest 2005;(2nd edition).

4. Dinas Pendidikan Provinsi Sumatera Barat. Pedoman Pengintegrasian Pendidikan Alqur'an Dan Budaya Alam Minangkabau Pada Materi Pelajaran Kimia SMA. Padang, Sumatera Barat: Dinas Pendidikan Provinsi Sumatera Barat; 2017.

5. Iryani, Mawardi and A. Pengaruh Penggunaan LKS Berbasis Inkuiri Terbimbing Terhadap Hasil Belajar Siswa Untuk Materi Koloid Kelas XI SMAN 1 Batusangkar. Eksakta 2016;1.

6. Rohmiyati, dkk. Pengembangan Modul Kimia Berbasis Inkuiri Terbimbing Pada Materi Reaksi Oksidasi Reduksi. I Inov Pendidik IPA 2016;2(2):223-9.

7. Rahmi A. Pengembangan Modul Hidrolisis Garam Berbasis Inkuiri Terbimbing Dengan Menggunakan Tiga Level Representasi Kimia. (Skripsi tidak diterbitkan). 2017;

8. Plomp T. Educational Design Research: An Introduction", dalam An Introduction to Educational Research. Enschede,
Netherland: National Institute for Curriculum Development; 2007.

9. Sugiyono. Metode Penelitian Kuantitatif, Kualitatif dan R\&D. Bandung: Alfabeta; 2013.

10. Boslaugh S dan PAW. Statistics in a Nutshell, a desktop quick reference. Beijing, Cambridge, Famham, Köln, Sebastopol, Taipei,Tokyo: O'reilly;

11. Suryosubroto B. Sistem Pengajaran dengan Modul. Yogyakarta: Bina Aksara; 1983. 